\title{
Designing a Competitive Advantage Model Through Dynamic Capabilities and Differentiation Approach for Iranian Knowledge-based Companies
}

\author{
Alireza Abdolhosseini Khaligh ${ }^{1}$, Mohammad Haghighi ${ }^{2}$, Mohsen Nazari ${ }^{3} \&$ Hamid Khodadad Hosseini ${ }^{4}$ \\ ${ }^{1}$ PhD Candidate of Business Administration, Alborz Campus, University of Tehran, Tehran, Iran \\ ${ }^{2}$ Associate Professor, Faculty of Management, University of Tehran, Tehran, Iran \\ ${ }^{3}$ Associate Professor, Faculty of Management, University of Tehran, Tehran, Iran \\ ${ }^{4}$ Professor, Faculty of Management and Economics, Tarbiat Modares University, Tehran, Iran \\ Correspondence: Alireza Abdolhosseini Khaligh, Alborz Campus, University of Tehran, Tehran, Iran. E-mail: \\ arkhaligh@ut.ac.ir \& arkhaligh@alum.sharif.edu
}

Received: May 27, $2020 \quad$ Accepted: August 11,2020 Online Published: September 1, 2020

doi:10.5539/jms.v10n2p52 URL: https://doi.org/10.5539/jms.v10n2p52

\begin{abstract}
The worldwide competitive struggles in high-tech environment such as knowledge-based companies have featured the necessity to infer how competitive advantage is gained. Dynamic capabilities as the origin of competitive advantage emphasize the changing character of the environment and nature of future competition, acceleration in innovation growth, and the main role of strategic management in adaption, integration, and reconfiguration of organizational skills, resources, and working competences toward shifting environment. The recent inquiry is based on an interpretive paradigm and an inductive approach. The qualitative part of the research is conducted with exploratory purpose through grounded theory strategy. In quantitative part of study, it is continued with explanatory and descriptive purposes through survey and correlational research strategies. The probe concepts and variables are analyzed in 30 top knowledge-based companies located at growth centers of 6 high-ranking universities of Iran working on electronics and informatics field. The results of the research indicate that achieving knowledge-centricity main phenomenon through dynamic capabilities requires presence of value creation on the basis of resource orientation together with competences. The knowledge-based companies can reach the summit and sustainable success in the knowledge-centricity main phenomenon when they consider two kinds of specialized paths related to the differentiation strategies and knowledge-based strategies. Along with these two paths, contextual factors of environmental cognition, knowledge management and knowledge approaches, and the intervening conditions of branding and brand management, and strategic agility are identified that have a positive and significant effect on both strategies. The final designed model explicates how to gain competitive advantage for the studied companies through dynamic capabilities with regard to the differentiation and the knowledge-based approaches.
\end{abstract}

Keywords: competitive advantage, competency, dynamic capabilities, strategic management, differentiation, knowledge-based strategies

\section{Introduction}

The companies' chief question in the field of strategic management is how to obtain and sustain competitive advantage. Confronting this challenge can be pursued by the dynamic capabilities approach, which opens the way for firms to analyze the sources of value creation. This approach is related to rivalry based on innovation, competition in pricing policies, optimization of performance, augmentation of returns, and creative alteration of preceding competences. With this approach, corporate-level success or failure can be justified. Reviewing accepted theories in strategic management exposes competitive conditions that can reflect competitive strategy. Despite the fact that many theories have been promoted during past three decades in the context of competitive advantage sources, only a few constructed theoretical frameworks have been configured. Capabilities are the skills of a firm to coordinate and employ resources efficiently. A capability can enable a company to produce unique and creative products and services. The organizational capability is regarded as the ability to change and accept financial, technological and strategic evolution. The firm's competences are made by capabilities which 
come together. The core competences are those competences by which the company can do things that the others are not able to do. Having these competences makes it easier to attain the competitive advantage. In this study, the researchers make an effort to achieve a novel perspective of gaining competitive advantage for a knowledge-based product or service through dynamic capabilities. The concept of dynamic capabilities supplements the fundamental proposition of the resource-based viewpoint of the company as a great and effective vigor. Dynamic capability is the ability beyond operational competence that not only enables companies to originate and invent, but also leads to profitable innovations. The universal competitive combats in high tech and knowledge-based companies have clearly revealed the necessity for an augmented paradigm to know how competitive advantage is obtained. In international markets, successful firms are able to demonstrate convenient responsiveness and product innovation, coupled with knowledge-based strategies to make customers not only buy a brand but also make them pull towards a differentiated product or service. Under this term, one knowledge-based company is able to coordinate and rearrange internal and external competences towards competitive advantage through dynamic capabilities.

\section{Research Literature, Frameworks and Scope}

\subsection{Literature and Theoretical Framework}

\subsubsection{Competitive Advantage}

A competitive advantage is an advantage attained over against competitors through offering higher values or lower prices for customers, providing additional benefits for a product or a service that can have a role of the justifier for possibly higher prices. Identifying and cultivating a competitive advantage can be considered as an increased profit or a sustainable and successful venture over the long term (Porter, 1990). Competitive advantage involves a set of factors or capabilities that enables the company to perform better than competitors (Barney, 1991). The rapid response that comes from the entrepreneurial orientation of the organization is regarded as a source of competitive advantage (Lumpkin \& Dess, 1996). Byrd and Turner (2001) used four dimensions of innovation, market position, imitation difficulty and mass customization to measure competitive advantage. An enterprise experiences competitive advantage in an industry or a market when its activities generate economic value and not many firms are engaged in similar activities. The most common definition of competitive advantage in the competition strategy area and the value creation context is whatever that will increase revenue beyond cost (Rumelt, 2003). An agile organization can have a successful performance in satisfying rapidly changing market needs and gain competitive advantage through the capabilities of responsiveness, competence, flexibility and speed in a competitive environment (Li, Ragu-Nathan, Ragu-Nathan, \& Rao, 2006). Four factors help a company to gain and retain competitive advantage, which contain efficiency, quality, innovation and customer responsiveness. Each of these factors is a distinctive competence for the company. In fact, they are general distinctive competences so far as they allow the company to differentiate its products presentation, offer more values to the customers, and lower its cost structure (Hill \& Jones, 2007). The reputation has an important role in value creation and competitive advantage (Sheehan \& Stabell, 2010). A company achieves competitive advantage when it creates more value for the customers than competitors, so that the customers find that company's products and services better than the competitors. Creating value can be achieved through the supply of products and services with lower price or higher quality or more benefits. Competitive advantage is measured in terms of cost, quality, competence and speed (Ambe, 2010). Strategic leadership capabilities affect competitive advantage (Mahdi \& Almsafir, 2014). Competitive advantage is identified as the rate of return higher than average (Wang \& Ahmed, 2007; Eriksson, 2014). In terms of performance, competitive advantage can operate alone or in a combination of multiple advantages interacting with each other as an integrated entity. In first case, it is considered as the sustainable competitive advantage; and in connection with time, it has a long-lasting function time and easily accessible by competitors (Kumar et al., 2015). The concept of competitive advantage is directly related to the customer's desired values (Evans, 2016). Competition in a global level generates new conditions of communications, and also a new level of quality in technological advance and new ways of gaining competitive advantage. One significant solution that leads to increase the enterprise efficiency is collaboration on business, globalization and knowledge. Inter-organizational relations are the source of competitive advantage for contemporary companies (Rzepka, 2017). Resources and capabilities along with strategies clarify competitive advantage, but their relevance and importance vary for each type of enterprise (Lorenzo, Rubio, \& Garcés, 2018). Innovation is the strategic tool in the competition for improvement, creation, and strengthening of business to create competitive advantage (Distanont \& Khongmalai, 2018). IT strategy and IT structure have a direct effect on competitive advantage (Saeidi et al., 2019). 


\subsubsection{Dynamic Capabilities}

In past years, a considerable number of researchers believe dynamic capabilities to be at the core of the corporate strategy to create value and gain competitive advantage (Eisenhardt \& Martin, 2000; Teece, 2007; Winter, 2003). Dynamic capabilities refer to the ability of a company or an organization to create manufacturing and service processes of new products in order to respond quickly to environmental changes (Helfat et al., 2009). Barrales-Molina et al. (2010) identify these capabilities as the ability of a company to integrate, build, and reconfigure internal and external skills in order to respond quickly to dynamic environments. Dynamic capabilities have been proposed as a means of removing turbulent environments with the help of managers to expand, refine, and reproduce existing operational capabilities to new ones compatible with the environment (Pavlou \& El Sawy, 2011). Jantunen et al. (2012) suggest that dynamic capabilities are the higher-order capabilities to modify operational and learning capabilities in new domains, and are therefore crucial for innovation activities. Many researchers consider dynamic capabilities as a process related to the ability of organizations in reconfiguring the resource bases. They confirm that dynamic capabilities get the organization to be involved with its resources in order to reform the operational capabilities and find new capabilities which lead to competitive advantage (Masteika \& Čepinskis, 2015). Dynamic capabilities are those organizational capabilities that allow companies to profit from producing differentiated products and services and manage the production of those which address new and existing market demands. Strong dynamic capabilities enable enterprises to produce not only the best type of product or service but also something that is unique and valuable (Pundziene \& Teece, 2016). For developing dynamic capabilities, it is suggested that firms improve the connections among their employees and empower their innovative potential. High-quality relationships and dialogue allow participants to advance and accept proposals for change even in the presence of conflicting viewpoints, and enhance the capacity to be flexible with market alterations (Salvato \& Vassolo, 2018). According to dynamic capabilities theory, entrepreneurs are more capable of sensing, seizing and reconfiguring resources and opportunities in vibrant entrepreneurial ecosystems (Roundy \& Fayard, 2018). Dynamic capabilities are more in the sense that organizations not only adapt to the business environment, but are mostly used to form it in many cases. These capabilities are part of a system that includes resources and strategy. The dynamic capabilities framework has been made to help organize and prioritize the infinite stream of competing and conflicting information that cascades toward managers as they try to gain competitive advantage. These capabilities specify what the company can do and how impressively it is able to make changes (David J Teece, 2018b).

\subsubsection{Differentiation Approach}

The effects of the differentiation approach on products manufacture are embodied in specific features of companies' products which can be mentioned in terms of design, size and color. Such features will be more prominent as incentives for customers to persuade and attract them to buy products (Stewart, 1996). Differentiation is one of the main factors influencing one's desire to be identified by the unique brands and organizations (Bhattacharya \& Sen, 2003). When one individual tends to be identified by the brand, differentiation in the brand will be the chief factor in its selection (Berger \& Heath, 2007). In technology service organizations (TSOs), the differentiation strategy and operational independence have been examined in the process of innovation and the results reveal that they have a positive impact on the innovation process (Das \& Joshi, 2007). According to the theory of being unique, the need for differentiation and being unique is one of the key elements of an individual's motivation to create a good sense of self (Berger et al., 2005). Emotions play an important role in the consumer's choice structure, which complicates the task of creating a differentiated marketing strategy. It means that suppliers need to give more consideration to consumers' self-awareness (Barrena \& Sánchez, 2009). Differentiation has a significant impact on the prices and profits of one company to the extent that having more competitive advantage is useful to retain and intensify the differentiation advantage against competitors ((Rong et al., 2013). Differentiation approach has a positive impact on contemporaneous performance of an organization that allows a firm to maintain its current performance in the future. The differentiation strategy is also associated with greater systematic risk (Banker et al., 2014). The differentiation strategy affects profitability and organizational growth. Choosing a differentiated and direct-to-consumer distribution channel can positively help the company to increase gross profit margin and growth rate of the organization (Newton, Gilinsky Jr, \& Jordan, 2015).

\subsubsection{Knowledge-Based Companies and Strategies}

Three categories of characteristics are effective on the growth of knowledge-based companies. These attributes are firm-specific characteristics, founder-specific ones and external factors (Almus \& Nerlinger, 1999). Knowledge is regarded as an advantage for knowledge-based companies in such a way that the companies are 
constantly updating their knowledge in order to be at least equal to their competitors (Wiklund \& Shepherd, 2003). By acknowledging the significance of science and technology in economic development, its logical consequence, namely the great importance of production capacity creation and innovation by knowledge-based companies becomes more apparent (Etzkowitz, 2006). Knowledge-based companies are deduced from the view on the basis of valuing the new opportunities connected to the knowledge-based economy and valuing the opportunities of the classical economy in a new way with emphasis on the importance of knowledge (Nicolescu, 2006). Three groups of individual, corporate and environmental factors influence the growth of new knowledge-based companies. Individual factors include gender, age, level of education, managerial and work experience, operational skills, training, successful and unsuccessful experiences; corporate factors contain company age, legal status; size, ownership and managerial characteristics, and finally environmental factors include confusion, heterogeneity, environmental dynamism, customer structure, location, competition and monopoly of the company (Rannikko, 2012). To become a knowledge-based company, a corporation employs university alumni in the first step. In the next step, it shifts its focus to use professionals who work on solving unusual problems. These problems require a combination of convergent, divergent and creative thinking (Massingham, 2008; Jennex \& Durcikova, 2013). In the modern world economy, which is called the knowledge economy, the importance of intangible resources is far greater than tangible resources, because their business requires more time. Therefore, knowledge-based companies need to develop intangible resources for their growth that the most important of which are brand resources (Rosenbaum-Elliott, Percy, \& Pervan, 2015). The new approaches to strategy and organization are the reflections of significant alterations in economics, business and knowledge management. These changes have led to the emergence of a new type of strategy, the so-called knowledge-based strategy, based on two components not commonly found in classical strategies. These two components are knowledge and learning. Knowledge is the most important strategic resource of the company and learning is the most influential skill of the organization (Zack, 1999). A set of main elements should be considered in the analysis, designing and using of the strategies based on knowledge. Theses elements include understanding the subject of a knowledge-based organization system and its need for change; focusing on the activities that make the virtual value chain of knowledge-based organization; identifying supporting and opposing forces to change; creating the vision for strategic change; presenting the organizational change message; the creation of the strategic coalition for change; creating a strategic coalition for change; building teams to reach final change; giving information, training and offering consultancy for the participants to change; allocating a remarkable part of time and budget for change by related managers of the knowledge-based company; reflecting this reality by the leaders of change processes, there is no turning back to the previous situation; intensive and close communications between participants for change; the strong involvement and participation of individuals from sectors that are subject to operational change processes; encouraging and supporting the staff creativity; the prudent but effective monitoring of the strategic change processes performance; the specified assessments of progress and results of strategic change; corrections and improvement operations during change; and building sustainable change through knowledge-based strategies (Whitehill, 1997).

Achieving the strategy based on knowledge of the organization is founded primarily on the same approach of logic and methodology as a classic business strategy. Knowledge has the indispensable and decisive role in the strategic knowledge based process to the extent that if a strategy is not developed, the knowledge management needs to conduct an audit of knowledge. It should be noted that it is not possible to achieve the operational strategy of knowledge without redesigning the knowledge management system. The changes which are of realities happen in the content of each phase because of the transition in the foreground of knowledge in many cases such as raw materials, capital input, product and competitive advantage (Muthusamy \& Palanisamy, 2004).

\section{Research Methodology}

\subsection{Research Process}

According to the main topic and purposes of the research, the induction approach has been employed to conduct the probe. All important data have been initially collected through qualitative research tools, and then after analyzing the data, a model has been designed and a theory has been developed. Afterwards, the research hypotheses have been made based on the relationships among the variables of the research model. In this study, the main framework of the research has been created through concepts derived from knowledge-based companies through both a series of in-depth interview data, and an accurate study on literature about competitive advantage, dynamic capabilities, competencies, knowledge, knowledge management, knowledge-based strategies, and differentiation and so on. Meticulous studying preceding researches on inquiry topic causes a better perception to be provided about the research concepts. This process feeds and advances the research as a 
better inductive research.

\subsection{Population Profile Data and Sampling Method}

The sampling method of this research is nonprobability and non-random with a purpose in mind involves a sample of persons with the demonstrable experience and expertise in the research issue, consisting of knowledge, knowledge-centricity, knowledge-based products (services) and knowledge-based companies and related issue (expert sampling). It has been carried out in 30 active knowledge-based companies in the field of electronics and informatics which have settled in the science and technology park of 6 top universities of Iran. At first, 78 knowledge-based companies are identified as target sample of the research and are preliminary evaluated. After initial evaluation and contact with these companies, fifty-four of them show willing to cooperate. Finally, five companies are selected from each university and totally 30 senior managers are deeply interviewed twice within eight months. During this period of time, more than forty hours of the interviewee's voice are recorded and four hundred pages of documentation are collected. The studied companies' field of activities, the university associated with each of them and the number of open codes extracted from the deep interview of each interviewee has been presented in the Table 1 .

Table 1. The number of open codes extracted from the in-depth interview with each respondent

\begin{tabular}{|c|c|c|c|c|c|c|c|}
\hline $\begin{array}{l}\text { KB Co. } \\
\text { Num. }\end{array}$ & $\begin{array}{l}\text { Interviewee } \\
\text { Num. and Name } \\
\text { of Uni. }\end{array}$ & $\begin{array}{l}\text { Field of } \\
\text { Scientific } \\
\text { Activities }\end{array}$ & $\begin{array}{l}\text { The Num. of Open } \\
\text { Codes Extracted } \\
\text { from Interview }\end{array}$ & $\begin{array}{l}\text { KB Co. } \\
\text { Num. }\end{array}$ & $\begin{array}{l}\text { Interviewee } \\
\text { Num. and Name } \\
\text { of Uni. }\end{array}$ & $\begin{array}{l}\text { Field of } \\
\text { Scientific } \\
\text { Activities }\end{array}$ & $\begin{array}{l}\text { The Num. of Open } \\
\text { Codes Extracted } \\
\text { from Interview }\end{array}$ \\
\hline KB Co. 1 & Int. 1 (UT 1) & Elec. & 80 Codes & KB Co. 16 & Int. 16 (IUST 1) & Elec. & 70 Codes \\
\hline KB Co. 2 & Int. 2 (UT 2) & Elec. & 72 Codes & KB Co. 17 & Int. 17 (IUST 2) & Elec. & 66 Codes \\
\hline KB Co. 3 & Int. 3 (UT 3) & Elec. & 77 Codes & KB Co. 18 & Int. 18 (IUST 3) & Elec. & 68 Codes \\
\hline KB Co. 4 & Int. 4 (UT 4) & Info. & 74 Codes & KB Co. 19 & Int. 19 (IUST 4) & Elec. & 70 Codes \\
\hline KB Co. 5 & Int. 5 (UT 5) & Info. & 76 Codes & KB Co. 20 & Int. 20 (IUST 5) & Elec. & 76 Codes \\
\hline KB Co. 6 & Int. 6 (SUT 1) & Elec. & 72 Codes & KB Co. 21 & Int. 21 (SBU 1) & Info. & 75 Codes \\
\hline KB Co. 7 & Int. 7 (SUT 2) & Info. & 78 Codes & KB Co. 22 & Int. 22 (SBU 2) & Info. & 72 Codes \\
\hline KB Co. 8 & Int. 8 (SUT 3) & Elec. & 75 Codes & KB Co. 23 & Int. 23 (SBU 3) & Info. & 79 Codes \\
\hline KB Co. 9 & Int. 9 (SUT 4) & Info. & 76 Codes & KB Co. 24 & Int. 24 (SBU 4) & Elec. & 76 Codes \\
\hline KB Co. 10 & Int.10 (SUT 5) & Elec. & 70 Codes & KB Co. 25 & Int. 25 (SBU 5) & Elec. & 75 Codes \\
\hline $\mathrm{KB}$ Co, 11 & Int. 11 (AUT 1) & Info. & 71 Codes & KB Co. 26 & Int. 26 (TMU 1) & Elec. & 76 Codes \\
\hline KB Co. 12 & Int. 12 (AUT 2) & Elec. & 74 Codes & KB Co. 27 & Int. 27 (TMU 2) & Elec. & 82 Codes \\
\hline KB Co. 13 & Int. 13 (AUT 3) & Elec. & 72 Codes & KB Co. 28 & Int. 28 (TMU 3) & Elec. & 85 Codes \\
\hline KB Co. 14 & Int. 14 (AUT 4) & Info. & 68 Codes & KB Co. 29 & Int. 29 (TMU 4) & Elec. & 81 Codes \\
\hline KB Co. 15 & Int. 15 (AUT 5) & Info. & 73 Codes & KB Co. 30 & Int. 30 (TMU 5) & Elec. & 74 Codes \\
\hline
\end{tabular}

Note. KB Co.: Knowledge-based Company; UT: University of Tehran; SUT: Sharif University of Technology; AUT: Amirkabir University of Technology; IUST: Iran University of Science and Technology; SBU: Shahid Beheshti University; TMU: Tarbiat Modares University; Elec.: Electronics and Related Fields; Info.: Informatics and Related Fields.

\subsection{Research Methods}

This inquiry is based on an interpretive paradigm and a postpositive philosophy. The research has been established upon an applied and a developmental orientation. It has started with an inductive approach. The qualitative methods have been used in the first part of the probe to build a model and the quantitative methods have been employed to denote the statistics, test the model and present its goodness of fit. This study is primarily initiated with exploratory purpose through grounded theory strategy; then, it is continued with explanatory and descriptive purposes with survey and correlational research strategies.

In qualitative part, applying the grounded theory, the researchers are able to seek and extract the concepts from the obtained data through deep interviews with senior managers of studied knowledge-based companies and conceptualize the latent patterns and structures. In the first stage of GT, after several rounds of punctilious review of obtained data, 308 open codes are extracted. In the next step, these open codes 83 axial codes come from sorting and categorization of the research open codes. Through a detailed study on the research literature, eight new codes are added to the previous axial codes, and the total axial codes of the research increases to 91 codes. In the third step of coding, with high precision and review of codes, the axial codes are grouped into 12 selective codes as the main variables of the research.

In the paper, the axial codes and selective codes are respectively shown in ' $\mathrm{B}$ ' and ' $\mathrm{C}$ '. These codes and their categorization have been represented in the following table. 
Table 2. Axial codes (indicators) and selective codes (variables) of the research

\begin{tabular}{|c|c|c|c|c|}
\hline $\begin{array}{l}\text { B } \\
\text { Code }\end{array}$ & Source & Factors (Axial Codes) & $\begin{array}{ll}\text { C } \\
\text { Code }\end{array}$ & $\begin{array}{l}\text { Construct (Selective } \\
\text { Codes) }\end{array}$ \\
\hline B1 & I1 L1 & $\begin{array}{l}\text { Correct Understanding of Quality, Quality Promotion and Supplying of } \\
\text { Higher Quality Products }\end{array}$ & $\mathrm{C} 1$ & $\begin{array}{l}\text { Competitive Advantage } \\
\text { (CA) }\end{array}$ \\
\hline B2 & I2 L2 & Cost Leadership & & \\
\hline B3 & I3 L3 & $\begin{array}{l}\text { Product Innovation, Innovative Capabilities and the Ability to Create } \\
\text { Knowledge }\end{array}$ & & \\
\hline B4 & I4 L4 & Organizational Capabilities & & \\
\hline B5 & I5 L5 & Creating Competitive Values with Direct Impact & & \\
\hline B6 & I6 L6 & Situational Advantage & & \\
\hline B7 & I7 L7 & Organizational Intelligence & & \\
\hline B8 & I8 L8 & Competitive Intelligence & & \\
\hline B9 & I9 L9 & $\begin{array}{l}\text { Providing the Requirements of a Changing Environment by Identifying and } \\
\text { Adapting to Environmental Change }\end{array}$ & $\mathrm{C} 2$ & $\begin{array}{l}\text { Environmental Cognition } \\
\text { (EC) }\end{array}$ \\
\hline $\mathrm{B} 10$ & I10 L10 & Environmental Status Analysis & & \\
\hline B11 & I11 L11 & Monetary and Financial Resources & $\mathrm{C} 3$ & Value Creation based on \\
\hline B12 & I12 L12 & Physical Capital Resources & & Resource Orientation \\
\hline B13 & I13 L13 & Human Capital Resources & & (RO) \\
\hline B14 & I14 L14 & Organizational Capital Resources & & \\
\hline B15 & I15 L15 & $\begin{array}{l}\text { Information Resources and Assets, Strong Databases and optimal Data } \\
\text { Utilization }\end{array}$ & & \\
\hline B16 & I16 L16 & Intangible Assets & & \\
\hline B17 & I17 L17 & Differentiation in Effective Procedures on Customer Experience & $\mathrm{C} 4$ & Differentiation Strategies \\
\hline B18 & L18 & Differentiation in Offering of Hybrid and Discrete Products (Services) & & (DS) \\
\hline B19 & I19 L19 & Differentiation in Product (Service) Integration & & \\
\hline B20 & I20 L20 & $\begin{array}{l}\text { Differentiation in Value Chain related to Product Support, Access to } \\
\text { Components and Information Systems }\end{array}$ & & \\
\hline B21 & I21 L21 & $\begin{array}{l}\text { Differentiate in Pricing and Offering of Products (Services) at Reasonable } \\
\text { Prices }\end{array}$ & & \\
\hline B22 & I22 L22 & Differentiation based on Mental Image & & \\
\hline B23 & I 23 L23 & Differentiate in Offering of Complementary Services & & \\
\hline B24 & I24 L24 & $\begin{array}{l}\text { Differentiation based on Distribution Channel, Ease of Access and Physical } \\
\text { Location }\end{array}$ & & \\
\hline B25 & I25 L25 & Differentiation in Product Performance, Benefits and Costs of Enjoyment & & \\
\hline B26 & I26 L26 & Differentiation in Accountability to Customer & & \\
\hline B27 & I27 L27 & Differentiation in Creating key Features in the Product (Service) & & \\
\hline B28 & I28 L28 & Differentiation in Special, Unique and Innovative Product Features & & \\
\hline B29 & I29 L29 & $\begin{array}{l}\text { Differentiation in New Product (Services) Offerings, and New Innovative } \\
\text { Product Development }\end{array}$ & & \\
\hline B30 & I30 L30 & $\begin{array}{l}\text { Differentiation in the Production Process and Line, and Relationship with } \\
\text { Different Parts of the Line Development }\end{array}$ & & \\
\hline B31 & I31 L31 & $\begin{array}{l}\text { Differentiation in Inimitability, or hardness and Imperfection of Imitation for } \\
\text { Competitors }\end{array}$ & & \\
\hline B32 & I32 L32 & Clarifying and Developing a Brand Strategy & $\mathrm{C} 5$ & Branding and Brand \\
\hline B33 & I33 L33 & Brand Identity & & Management (BR) \\
\hline B34 & $\mathrm{I} 34$ & Brand Sustainability and Dynamics & & \\
\hline B35 & I35 L35 & Brand Equity & & \\
\hline B36 & I36 L36 & Touch Points Creation & & \\
\hline B37 & $\mathrm{I} 37$ & Brand Commitment and Persistence & & \\
\hline B38 & I38 L38 & Integrated Marketing Communications (IMC) & & \\
\hline B39 & I39 L39 & $\begin{array}{l}\text { Strategic Sensitivity, Consciousness in Understanding the Business } \\
\text { Environment, and Business Awareness }\end{array}$ & C6 & Strategic Agility (SA) \\
\hline B40 & I40 L40 & $\begin{array}{l}\text { A Vivid and Clear Vision with an Overall View and a Long-term (Strategic) } \\
\text { Mainstream }\end{array}$ & & \\
\hline B41 & I41 L41 & Selection of the Strategic Knowledge Goals & & \\
\hline B42 & I42 L42 & $\begin{array}{l}\text { Identification of required Key Capabilities to Achieve the Technological } \\
\text { Knowledge Goals }\end{array}$ & & \\
\hline B43 & L43 & Collective Commitment (Leadership Unity and Collective Commitment) & & \\
\hline B44 & I44 L44 & Fluidity of Resources & & \\
\hline B45 & I45 L45 & The Preparation for Commercialization & & \\
\hline
\end{tabular}




\begin{tabular}{|c|c|c|c|c|}
\hline B46 & I46 L46 & Being Proactive & & \\
\hline B47 & I47 L47 & The Alignment of People, Processes and Technology & & \\
\hline B48 & I48 L48 & $\begin{array}{l}\text { Flexibility and Adaptability along with Better Understanding and } \\
\text { Improvement of Competitive Capabilities }\end{array}$ & & \\
\hline B49 & I49 L49 & The Change in the Strategic Performance of the Company & & \\
\hline B50 & I50 L50 & The Change in the Value Creation and Delivery Approach & & \\
\hline B51 & $\mathrm{I} 51$ & The Change in the Approach of Making Money from Created Value & & \\
\hline B52 & I52 L52 & $\begin{array}{l}\text { Rapid Response to Opportunities and Threats and exploitation of them upon } \\
\text { Identification and Recognition of their Importance (Sensing Capacity) }\end{array}$ & $\mathrm{C} 7$ & $\begin{array}{l}\text { Dynamic Capabilities } \\
\text { (DC) }\end{array}$ \\
\hline B53 & L53 & The Perceptions (Seizing Capacity) & & \\
\hline B54 & I54 L54 & $\begin{array}{l}\text { Reconstruction, Modification, Revitalization, Reconstruction and Recreation } \\
\text { Capabilities of the Organization, Business Models and Strategies } \\
\text { (Reconfiguration Capacity) }\end{array}$ & & \\
\hline B55 & I55 L55 & The Renewable Capabilities & & \\
\hline B56 & L56 & The Absorbing Capabilities & & \\
\hline B57 & I57 & Configuring the processes by positions and paths & & \\
\hline B58 & I58 L58 & Intra-organizational Position (Internal Strategic Status of the Organization) & & \\
\hline B59 & I59 L59 & $\begin{array}{l}\text { External Position of the Organization (External Strategic Status of the } \\
\text { Organization) }\end{array}$ & & \\
\hline B 60 & I60 L60 & Intrinsic Activators (Intrinsic Activating Factors) of Dynamic Capabilities & & \\
\hline B61 & I61 L61 & Extrinsic Activators (Extrinsic Activating Factors) of Dynamic Capabilities & & \\
\hline B62 & I62 L62 & The Improvement of Organizational Efficiency & & \\
\hline B63 & I63 & $\begin{array}{l}\text { Leveraging of Intra-organizational Strengths, Exploiting and Ultimate Use of } \\
\text { Competitors Mistakes, Overtaking and Overcoming them. }\end{array}$ & & \\
\hline B64 & I64 L64 & Occupational Competencies & $\mathrm{C} 8$ & Competencies (CO) \\
\hline B65 & I65 L65 & Individual and Interpersonal Competencies (Individual Level) & & \\
\hline B66 & I66 L66 & Technical and Technological Competencies & & \\
\hline B67 & I67 L67 & Executive Competencies & & \\
\hline B68 & I68 L68 & Organizational Competencies (Organizational Level) & & \\
\hline B69 & I69 L69 & Market Access (Marketing) Competencies & & \\
\hline B70 & L70 & $\begin{array}{l}\text { Integrative Competencies (The Combination of Technological and Marketing } \\
\text { Competencies) }\end{array}$ & & \\
\hline B71 & I71 L71 & Intellectual and Mental Competencies & & \\
\hline B72 & I72 L72 & Behavioral and personality-related Competencies (Personality Traits) & & \\
\hline B73 & L73 & $\begin{array}{l}\text { Essential Competences based on Internal Conformity, Stability and } \\
\text { Comprehensiveness }\end{array}$ & & \\
\hline B74 & I74 L74 & The Approaches based on the Nature of Knowledge Work & C9 & Knowledge Approaches \\
\hline B75 & I75 L75 & The Approaches based on the Knowledge Attitude & & (KA) \\
\hline B76 & I76 L76 & $\begin{array}{l}\text { Strategic Orientation, Sageness-centricity, and Innovative Culture } \\
\text { Development }\end{array}$ & $\mathrm{C} 10$ & $\begin{array}{l}\text { Knowledge Management } \\
(\mathrm{KM})\end{array}$ \\
\hline B77 & I77 L77 & Tendency to the Knowledge Development, Transfer and Support & & \\
\hline B78 & I78 L78 & $\begin{array}{l}\text { Sharing and Utilization of the Knowledge, and Participation in Providing } \\
\text { Services }\end{array}$ & & \\
\hline B79 & I79 L79 & The Knowledge Communications & & \\
\hline B80 & I80 L80 & The Knowledge Work Training and Coaching & & \\
\hline B81 & L81 & The Knowledge Policy and Strategy & & \\
\hline B82 & I82 L82 & Capturing and Acquisition of the Knowledge & & \\
\hline B83 & I83 L83 & The Close and Prepared Background for the Knowledge Activities & $\mathrm{C} 11$ & Knowledge-based \\
\hline B84 & I84 L84 & Dynamics in Goals & & Strategies (KS) \\
\hline B85 & I85 L85 & $\begin{array}{l}\text { The Growth-centricity and Continuous Technological Innovation with } \\
\text { Enjoyment of the Knowledge Resources and Capabilities, and Attention to } \\
\text { the Competitors Information }\end{array}$ & & \\
\hline B86 & I86 L86 & The Scope of Knowledge Thinking & & \\
\hline B87 & I87 L87 & The Nature of the Knowledge Vision & & \\
\hline B88 & I88 L88 & $\begin{array}{l}\text { Knowledge-centricity Emphasizing on R\&D and Economic Activities along } \\
\text { with R\&D Activities }\end{array}$ & $\mathrm{C} 12$ & $\begin{array}{l}\text { Knowledge-centricity } \\
(\mathrm{KC})\end{array}$ \\
\hline B89 & I89 L89 & Knowledge-centricity based on Geographical Centralization & & \\
\hline B90 & L90 & Spin-off Knowledge-centricity & & \\
\hline B91 & I91 L91 & Knowledge-centricity with High-tech and New Technology & & \\
\hline
\end{tabular}

Note. I: Interview; L: Literature; I L: Both Interview and Literature. 
In above table, 78 axial codes are observed in both in-depth interviews with experts and research literature. 8 axial codes have been extracted solely from the theoretical contents and the literature; and 5 axial ones have been derived from the interviews.

Table 3. Axial codes (indicators) extracted from the research literature and theoretical contents

\begin{tabular}{ll}
\hline Factors & Authors and Researchers \\
\hline L18 & Venkatesh, Berry, \& Dotzel, 2009; Paun, 1993 \\
L43 & Kosonen \& Dotz, 2007; Badawy, 2008 \\
L53 & Bogodistov et al., 2017; David J Teece, 2018a; David J Teece, 2018b; Ambrosini \& Bowman, 2009 \\
L56 & Easterby-Smith et al., 2008; Volberda, Foss, \& Lyles, 2010; Cabral, 2010; David J Teece, 2018b \\
L70 & Tuten, 2010; Ya-Hui \& Chia-Hsiu, 2015; Kak \& Sushil, 2002; Fowler et al., 2000; Fowler et al., 2000 \\
L73 & Camisón, 2004; Lawler III, 1994 \\
L81 & Davenport \& Prusak, 1998; Nonaka \& Takeuchi, 1995; Nonaka, Von Krogh, \& Voelpel, 2006; Davenport, De Long, \& Beers, \\
& 1998; Souza, 2012; Grant \& Baden-Fuller, 2004 \\
L90 & Cooper, 1971; Klepper \& Sleeper, 2005; Garvin, 1983 \\
\hline
\end{tabular}

\subsection{Research Model}

After studying the subject background in foreign and local literature, four generalized and open questions have been regarded as the main questions of the research. The initial conceptual model of the research has been designed considering twelve macro categories and the contextual model. These twelve macro categories have been supposed as main constructs (latent variables) of the study. Value Creation based on Resource Orientation (RO), Dynamic Capabilities (DC) and Competences (CO) form causal conditions. The core phenomenon of the research is Knowledge-centricity $(\mathrm{KC})$. Three variables of Environmental Cognition (EC), Knowledge Approaches (KA) and Knowledge Management (KM) constitute contextual conditions. Intervening conditions include Branding and Brand Management (BR), and Strategic Agility (SA). Differentiation Strategies (DS) and Knowledge-based Strategies (KS) are regarded as the main strategies of the research model; and consequently, it is expected that the knowledge-based companies gain competitive advantage through this model.

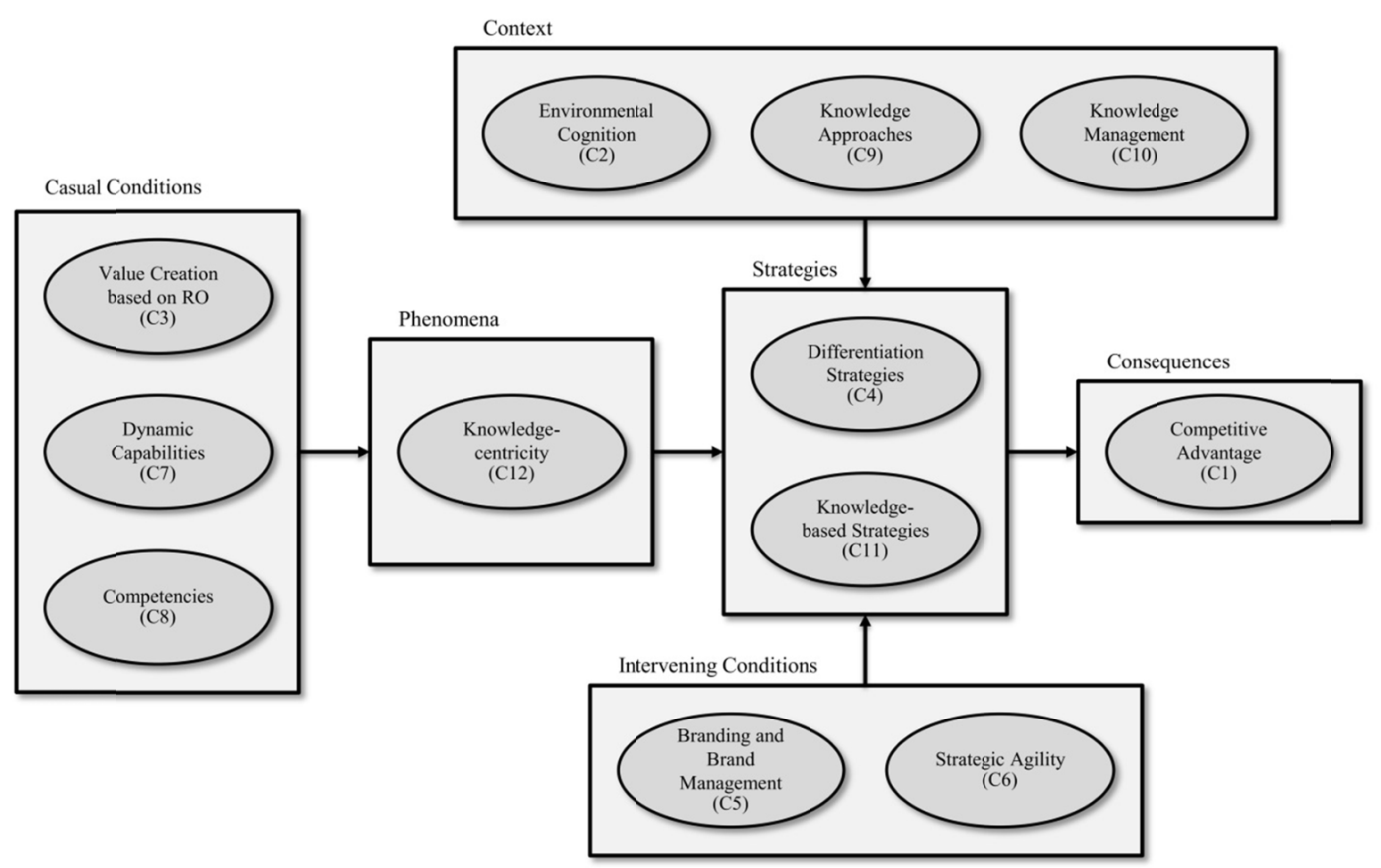

Figure 1. The extracted contextual model of the research 


\subsection{Research Hypotheses}

In this paper, we start the probe with this question that how a knowledge-based company is able to attain competitive advantage. Which tools, elements, factors, strategies and features are required that actively and competitively involve a knowledge-based company in markets to achieve the summit? To answer this multidimensional technical question, the qualitative part of the research is conducted and the initial model is designed based on the qualitative research findings. For testing the model which includes seventeen causal relations, the research hypotheses are formed. These hypotheses are as the following.

Table 4. Research hypotheses in path analysis

\begin{tabular}{ll}
\hline Num. & Research Hypotheses \\
\hline H1 & RO (C3) has a positive and meaningful impact on KC (C12). \\
H2 & DC (C7) has a positive and meaningful impact on KC (C12). \\
H3 & CO (C8) has a positive and meaningful impact on KC (C12). \\
H4 & KC (C12) has a positive and meaningful impact on DS (C4). \\
H5 & KC (C12) has a positive and meaningful impact on KS (C11). \\
H6 & EC (C2) has a positive and meaningful impact on DS (C4). \\
H7 & EC (C2) has a positive and meaningful impact on KS (C11). \\
H8 & KA (C9) has a positive and meaningful impact on DS (C4). \\
H9 & KA (C9) has a positive and meaningful impact on KS (C11). \\
H10 & KM (C10) has a positive and meaningful impact on DS (C4). \\
H11 & KM (C10) has a positive and meaningful impact on KS (C11). \\
H12 & BR (C5) has a positive and meaningful impact on DS (C4). \\
H13 & BR (C5) has a positive and meaningful impact on KS (C11). \\
H14 & SA (C6) has a positive and meaningful impact on DS (C4). \\
H15 & SA (C6) has a positive and meaningful impact on KS (C11). \\
H16 & DS (C4) has a positive and meaningful impact on CA (C1). \\
H17 & KS (C11) has a positive and meaningful impact on CA (C1). \\
\hline
\end{tabular}

The initial extracted model of the research from the combination of GT method obtained codes and research literature in-depth study acquired codes is formed as follows, consisting of 12 constructs and 91 primary indicators. 


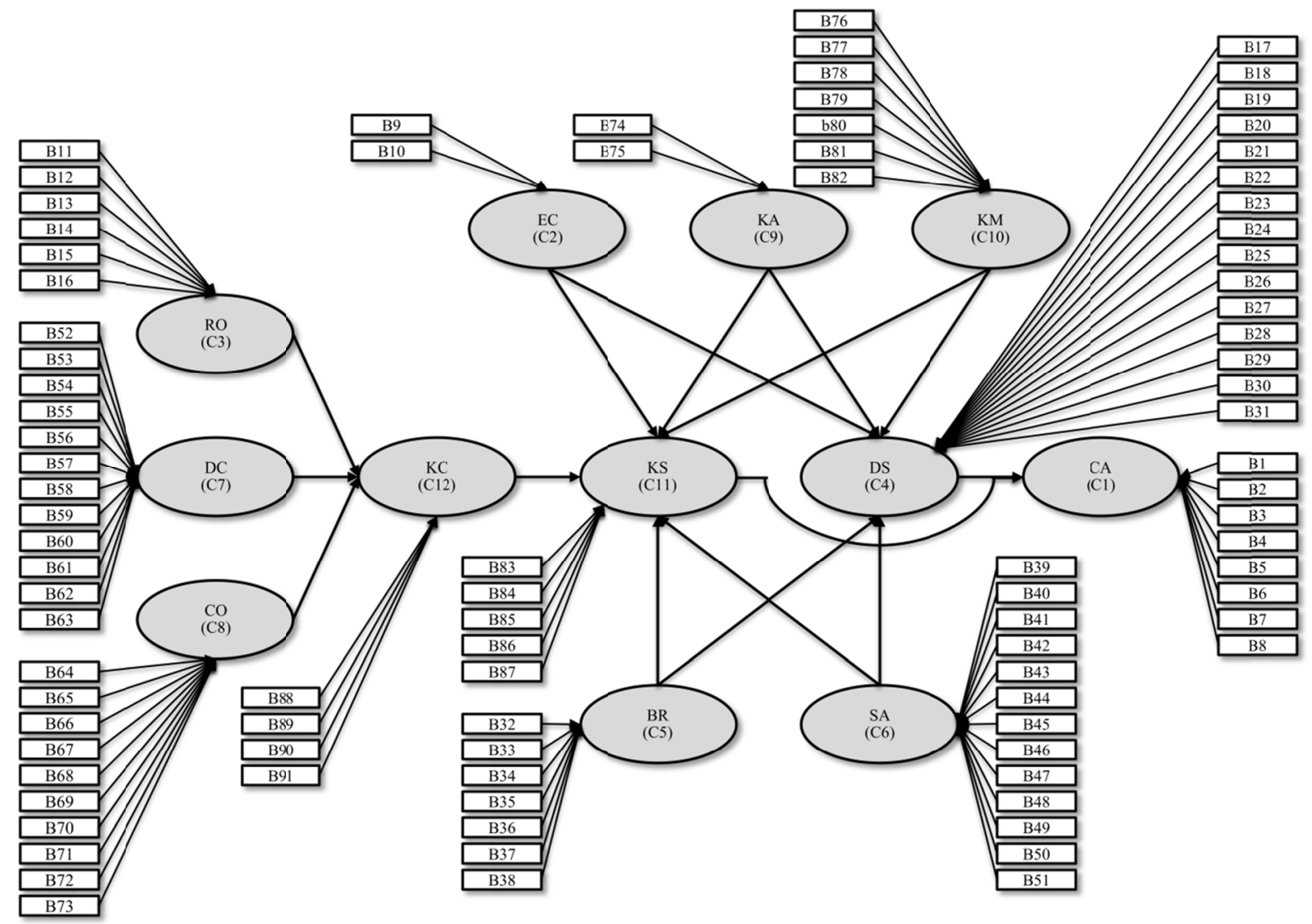

Figure 2. The extracted conceptual model of the qualitative research with constructs and factors

\subsection{Data Collection}

In the quantitative part of the research, survey and correlation strategies are the main research strategies used in direction of testing the built model in qualitative part. Considering the research subject and under the studied variables, the required information to test the hypotheses is collected through a questionnaire with interview. The target audiences of the questionnaire are the senior managers of the same 30 knowledge-based companies who have been interviewed in qualitative section of the probe. The final version of the questionnaire contains 114 questions. The questionnaire is divided into 3 types of questions. The first part includes context and demographic questions. The second part is a set of questions related to the components of 12 variables; and the last part is used to evaluate the main constructs of the research as total evaluators.

\subsection{Research Measures}

In this article, twelve main constructs are evaluated through structured survey. Indicators are the defining factors of each construct as any change in the components of a construct can affect the related variable. Removing any of the indicators may alter the concept of the respective construct and disrupt the overall structure of the model. The structural equation modeling and the covariance structure are used for better analysis of the obtained model of this research. In the present study, the researchers have applied path analysis to estimate and interpret the relationship of variables in the model. These relationships can be correctly interpreted through estimating the values. In fact, the estimated values represent the significance of the relationships. In structural equation modeling, estimation means the measurement of relationships intensity, and evaluation signifies that how much of fitness there is between the data collected by the researchers and their developed model adapted from the theoretical frameworks. In this research, the partial least squares (PLS) approach has been used to evaluate, estimate and interpret the relationships, and also to fit the model. 


\section{Data Analysis and Findings}

\subsection{The Technical Properties of Measuring Tools}

The credibility of each research depends on credibility of data collection tools of that research. The researchers have evaluated the technical properties of the tools especially questionnaires with interviews used in this study to ensure the accuracy of the obtained results.

\subsubsection{The Loading of Indicators}

The value of Loadings is obtained through calculating the correlation of the indicators of a construct with that construct. If this value is equal to or higher than 0.4 , it points out that the variance between a construct and its indicators is greater than the variance of measurement error and, therefore the reliability is acceptable for that measurement part of the model. Of course, some authors such as Rivard and Huff (1988) recommended the measure of 0.5 as the criterion for loadings.

The PLS has been used for initial evaluation of loadings of the measurement parts of the research model. In the beginning, after software calculation, the acquired loading value of 13 indicators is less than 0.5 and the rest are above the benchmark value. By removing indicators with low loading values from related constructs, loadings of residual indicators in the modified model are evaluated by the software again and finally, the loading values of 78 remaining indicators in the model are above 0.5 which represents acceptable reliability for all measurement parts of the model. The loadings of all indicators have been given in the table below.

Table 5. The loadings of indicators related to the model's constructs

\begin{tabular}{|c|c|c|c|c|c|c|c|c|c|c|c|c|c|c|c|}
\hline & B1 & B2 & B3 & B4 & B5 & B6 & B7 & B8 & & & & & & & \\
\hline \multirow[t]{2}{*}{$\mathrm{C} 1$} & .667 & .757 & .713 & Ex. F & .664 & .832 & .862 & .792 & & & & & & & \\
\hline & B9 & B10 & & & & & & & & & & & & & \\
\hline \multirow[t]{2}{*}{$\mathrm{C} 2$} & .866 & .845 & & & & & & & & & & & & & \\
\hline & B11 & B12 & B13 & B14 & B15 & B16 & & & & & & & & & \\
\hline \multirow[t]{2}{*}{ C3 } & .838 & .582 & .805 & Ex. F & .723 & .876 & & & & & & & & & \\
\hline & B17 & B18 & B19 & B20 & B21 & B22 & B23 & B24 & B25 & B26 & B27 & B28 & B29 & B30 & B31 \\
\hline \multirow[t]{2}{*}{$\mathrm{C} 4$} & Ex. F & .887 & .582 & Ex. F & .759 & .821 & .734 & .563 & .775 & .716 & Ex. F & .645 & .547 & .646 & Ex. F \\
\hline & B32 & B33 & B34 & B35 & B36 & B37 & B38 & & & & & & & & \\
\hline \multirow[t]{2}{*}{$\mathrm{C} 5$} & .707 & .853 & .591 & .747 & Ex. F & .746 & .796 & & & & & & & & \\
\hline & B39 & B40 & B41 & B42 & B43 & B44 & B45 & B46 & B47 & B48 & B49 & B50 & B51 & & \\
\hline \multirow[t]{2}{*}{ C6 } & .709 & .780 & .689 & .505 & .695 & .727 & .808 & .636 & Ex. F & .527 & .561 & .789 & .637 & & \\
\hline & B52 & B53 & B54 & B55 & B56 & B57 & B58 & B59 & B60 & B61 & B62 & B63 & & & \\
\hline \multirow[t]{2}{*}{ C7 } & .667 & .725 & .829 & .755 & .783 & Ex. F & .602 & .664 & .802 & .879 & .792 & .658 & & & \\
\hline & B64 & B65 & B66 & B67 & B68 & B69 & B70 & B71 & B72 & B73 & & & & & \\
\hline \multirow[t]{2}{*}{ C8 } & .877 & .682 & .684 & .689 & .738 & .674 & .855 & Ex. F & .556 & .832 & & & & & \\
\hline & B74 & B75 & & & & & & & & & & & & & \\
\hline \multirow[t]{2}{*}{ C9 } & .879 & .846 & & & & & & & & & & & & & \\
\hline & B76 & B77 & B78 & B79 & B80 & B81 & B82 & & & & & & & & \\
\hline \multirow[t]{2}{*}{$\mathrm{C} 10$} & .654 & .717 & .737 & .886 & Ex. F & .731 & .879 & & & & & & & & \\
\hline & B83 & B84 & B85 & B86 & B87 & & & & & & & & & & \\
\hline \multirow[t]{2}{*}{$\mathrm{C} 11$} & Ex. F & .846 & .782 & .813 & .868 & & & & & & & & & & \\
\hline & B88 & B89 & B90 & B91 & & & & & & & & & & & \\
\hline $\mathrm{C} 12$ & .815 & Ex. F & .743 & .840 & & & & & & & & & & & \\
\hline
\end{tabular}

Note. Ex.: The excluded factor from the initial research model through covariance structure for model fitting.

In Table 5, the indicators of each construct (B) have been ranked based on the intensity of effect on the connected construct $(\mathrm{C})$ in order to identify the most influential indicators of the model. 
Table 6. The ranking of the constructs' indicators in terms of efficacy ( $\beta$ coefficient $)$ in the related variable

\begin{tabular}{|c|c|c|c|c|c|c|c|c|c|c|c|c|}
\hline & 1 & 2 & 3 & 4 & 5 & 6 & 7 & & & & & \\
\hline \multirow[t]{2}{*}{$\mathrm{C} 1$} & B3 & B6 & B2 & B8 & B5 & B7 & B1 & & & & & \\
\hline & 1 & 2 & & & & & & & & & & \\
\hline \multirow[t]{2}{*}{$\mathrm{C} 2$} & B9 & B10 & & & & & & & & & & \\
\hline & 1 & 2 & 3 & 4 & 5 & & & & & & & \\
\hline \multirow[t]{2}{*}{ C3 } & B13 & B16 & B11 & B12 & B15 & & & & & & & \\
\hline & 1 & 2 & 3 & 4 & 5 & 6 & 7 & 8 & 9 & 10 & 11 & \\
\hline \multirow[t]{2}{*}{$\mathrm{C} 4$} & B26 & B23 & B18 & B21 & B30 & B19 & B24 & B29 & B28 & B22 & B25 & \\
\hline & 1 & 2 & 3 & 4 & 5 & 6 & & & & & & \\
\hline \multirow[t]{2}{*}{ C5 } & B35 & B33 & B37 & B38 & B32 & B34 & & & & & & \\
\hline & 1 & 2 & 3 & 4 & 5 & 6 & 7 & 8 & 9 & 10 & 11 & 12 \\
\hline \multirow[t]{2}{*}{ C6 } & B41 & B46 & B51 & B49 & B40 & B50 & B44 & B45 & B48 & B43 & B39 & B42 \\
\hline & 1 & 2 & 3 & 4 & 5 & 6 & 7 & 8 & 9 & 10 & 11 & \\
\hline \multirow[t]{2}{*}{ C7 } & B62 & B56 & B59 & B60 & B53 & B58 & B52 & B55 & B61 & B63 & B54 & \\
\hline & 1 & 2 & 3 & 4 & 5 & 6 & 7 & 8 & 9 & & & \\
\hline \multirow[t]{2}{*}{ C8 } & B73 & B70 & B68 & B67 & B65 & B66 & B69 & B64 & B72 & & & \\
\hline & 1 & 2 & & & & & & & & & & \\
\hline \multirow[t]{2}{*}{ C9 } & B74 & B75 & & & & & & & & & & \\
\hline & 1 & 2 & 3 & 4 & 5 & 6 & & & & & & \\
\hline \multirow[t]{2}{*}{$\mathrm{C} 10$} & B81 & B79 & B77 & B78 & B76 & B82 & & & & & & \\
\hline & 1 & 2 & 3 & 4 & & & & & & & & \\
\hline \multirow[t]{2}{*}{$\mathrm{C} 11$} & B84 & B86 & B87 & B85 & & & & & & & & \\
\hline & 1 & 2 & 3 & & & & & & & & & \\
\hline $\mathrm{C} 12$ & B90 & B88 & B91 & & & & & & & & & \\
\hline
\end{tabular}

\subsubsection{Path Analysis for Variables Causal Relationships}

The important issue in fitting the final model of the research indispensable to be assessed is the efficacy and the significance of the causal relationship between the research variables. The criterion for measuring the causal relationship between constructs in the structural part of the model is the T-Value, and the criterion of efficacy is the standardized beta coefficient $(\beta)$ or the path coefficient. If the T-Value of path between two constructs is greater than 1.96, it represents a relationship between constructs and thus confirms the hypothesis that one construct (variable) affects another construct (variable) in a 95\% confidence interval.

The standardized beta coefficient $(\beta)$ exposes that how much change it takes in dependent variable (effect) for one-unit change in independent variable (cause). In accordance with Table VII, all T-Values for the paths between two constructs are more than 1.96 and hence, all the relationships in the research model are significant and the hypotheses related to the causal relationships are accepted. The values of standardized beta coefficient ( $\beta$ ) for the model paths show that in 15 paths, the efficacy is high; in path $11(\mathrm{C} 10-\mathrm{C} 11)$, it is average; and in path 14 (C6 - C4), it is low.

Table 7. The results of structural equation modeling for variables causal relationship

\begin{tabular}{lllll}
\hline Num. & Path & Beta $(\beta)$ & T-Value & Hypothesis \\
\hline 1 & C3 - C12 & 0.675 & 4.838 & Accepted (High) \\
2 & C7 - C12 & 0.736 & 5.758 & Accepted (High) \\
3 & C8 - C12 & 0.703 & 5.234 & Accepted (High) \\
4 & C12 - C4 & 0.772 & 6.417 & Accepted (High) \\
5 & C12 - C11 & 0.712 & 5.370 & Accepted (High) \\
6 & C2 - C4 & 0.833 & 7.980 & Accepted (High) \\
7 & C2 - C11 & 0.599 & 3.959 & Accepted (High) \\
8 & C9 - C4 & 0.735 & 5.738 & Accepted (High) \\
9 & C9 - C11 & 0.536 & 3.363 & Accepted (High) \\
10 & C10 - C4 & 0.780 & 6.586 & Accepted (High) \\
11 & C10 - C11 & 0.444 & 2.623 & Accepted (Average) \\
12 & C5 - C4 & 0.802 & 7.115 & Accepted (High) \\
13 & C5 - C11 & 0.539 & 3.390 & Accepted (High) \\
14 & C6 - C4 & 0.304 & 1.987 & Accepted (Low) \\
15 & C6 - C11 & 0.680 & 4.912 & Accepted (High) \\
16 & C4 - C1 & 0.671 & 4.793 & Accepted (High) \\
17 & C11 - C1 & 0.578 & 3.747 & Accepted (High) \\
\hline
\end{tabular}


The following model is the final Structural Equations based model of the research that includes all the studied variables and their indicators. The indicators of each variable are considered after elimination of factors containing weak loading values, indispensable calculations in path analysis and fitting of the measuring parts of the model by PLS software. In the final model, considering the calculations of measuring and structural parts fitting criterion, the path coefficients have been denoted on paths.

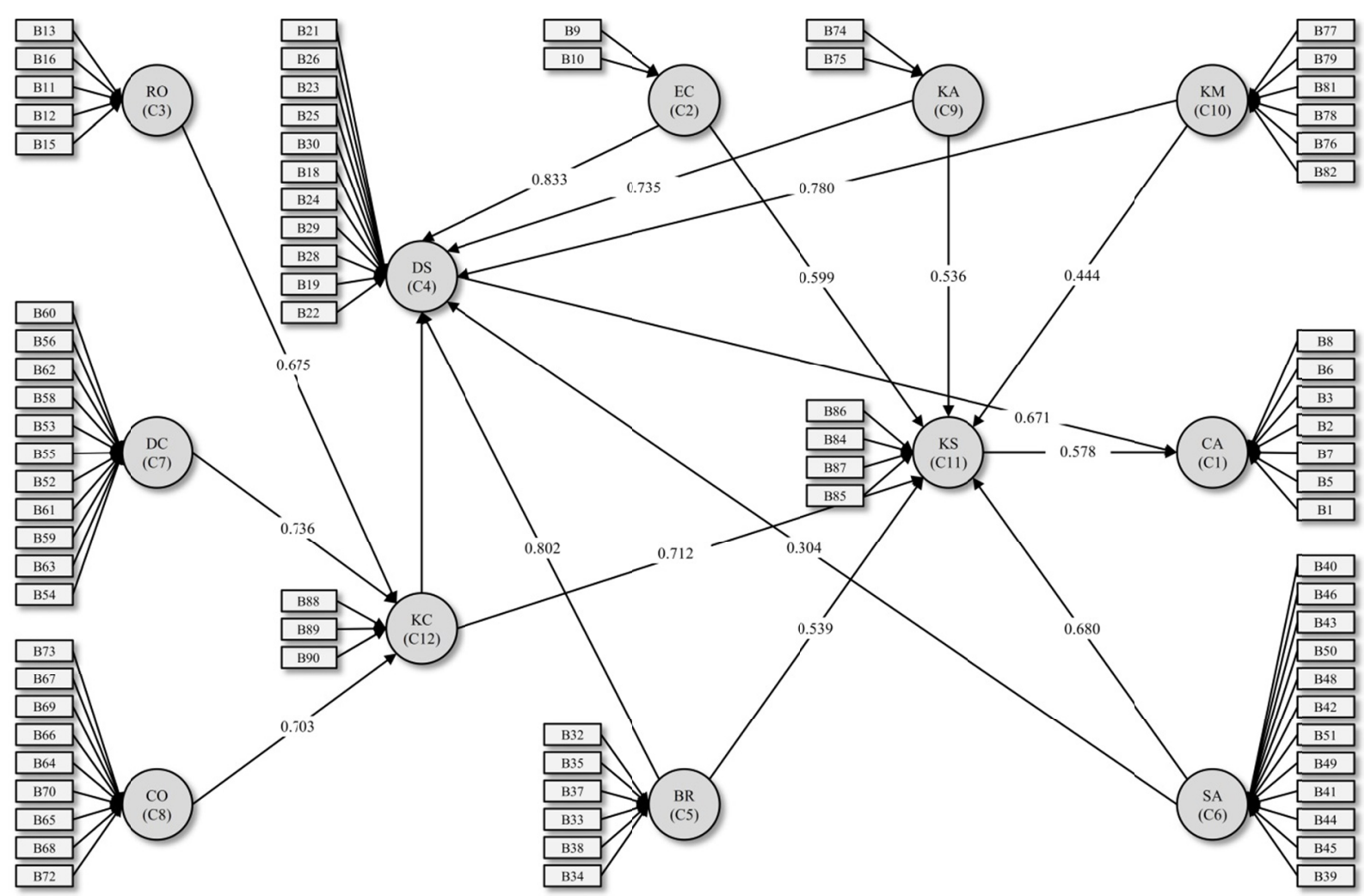

Figure 3. The final structural equations based model of the research with path analysis through PLS

\section{Results and Discussion}

In developed countries, a lot of successful corporations are about to gain competitive advantage through the knowledge-based capabilities since the production, distribution and utilization of knowledge are conceived as the keys to develop, growth and wealth creation in most fields for them. The existence of these companies leads to the emergence of the dynamic type of economy called the knowledge-based economy. This type of economy is made up of a vast network of knowledge-based companies that attempt to make a knowledge-based business in order to covert knowledge into wealth. These companies' economic activities are based on and associated with research and development operations in the field of new and developed technologies. These activities include all functions that commercialize their R\&D outcomes such as design, production, supplying goods or applications, technology generation and delivery, utilization of advanced technologies with added value, consultancy, and presentation of technical and knowledge-based services. This probe has been carried out on 30 knowledge-based companies active in the fields of electronics and informatics. The results of an in-depth interview with their experts and a precise study on research literature, theoretical frameworks and concepts which has led to a comprehensive model show that achieving knowledge-centricity main phenomenon through dynamic capabilities requires presence of value creation on the basis of resource orientation together with competences. In accordance with final model of the research, the knowledge-based companies can attain a meaningful success and reach the summit and sustainable success in the knowledge-centricity main phenomenon when they pay particular attention to two kinds of specialized strategies in parallel. The first one is the path related to the differentiation strategies and the second is the path of knowledge-based strategies. Along with these two paths of strategies, contextual factors such as environmental cognition, knowledge management and knowledge approaches have a positive and significant effect on both strategies. The efficacy of these factors on the differentiation strategies is higher than on knowledge-based strategies. The intervening conditions that affect both strategies are the 
branding and brand management, and also strategic agility for these knowledge-based companies. Branding and brand management have the most profound effect on differentiation strategies whereas strategic agility has the most intensive effect on knowledge-based strategies. As a conclusion, the most influential indicators related to model variables in order to gain competitive advantage are as follows. (1) In casual conditions, a knowledge-based company should consider (I) Resource Orientation (RO) such as human capital resources (B13), intangible assets (B16), and monetary and financial resources (B11); (II) Dynamic Capabilities (DC) like the improvement of organizational efficiency (B62), the absorbing capabilities (B56), and external position of the organization (B59); (III) Competencies (CO) such as essential competences based on internal conformity, stability and comprehensiveness (B73), integrative competencies (B70), and Organizational Competencies (B68). (2) In core phenomenon, it should regard to (IV) Knowledge-centricity (KC) like for example spin-off knowledge-centricity (B90), knowledge-centricity emphasizing on R\&D and economic activities along with R\&D activities (B88), and knowledge-centricity with high-tech and new technology (B91). (3) In core strategies, it is important for such a company to contemplate how to attain and execute (V) Differentiation Strategies (DS) like differentiation in accountability to customer (B26), differentiation in offering of complementary services (B23), and differentiation in offering of hybrid and discrete products or services (B18); (VI) Knowledge-based Strategies (KS) for example dynamics in goals (B84), the scope of knowledge thinking (B86), and the nature of the knowledge vision (B87). (4) In contextual conditions, it is significant for a knowledge-based company to remark on (VII) Environmental Cognition (EC) like providing the requirements of a changing environment by identifying and adapting to environmental change (B9), and environmental status analysis (B10); (VIII) Knowledge Approaches (KA) such as the approaches based on the nature of knowledge work (B74), and the approaches based on the knowledge attitude (B75); (IX) Knowledge Management (KM) covering the knowledge policy and strategy (B81), the knowledge communications (B79), and tendency to the knowledge development, transfer and support (B77). (5) In intervening conditions, it is essential for such a company to take into account the $(\mathrm{X})$ Branding and Brand Management (BR) like with subcategories such as brand equity (B35), brand identity (B33), and brand commitment and persistence (B37); (XI) Strategic Agility (SA) with indicators like selection of the strategic knowledge goals (B41), Being Proactive (B46), and the change in the approach of making money from created value (B51). (6) For reaching the final consequence of the research means (XII) Competitive Advantage (CA), a knowledge-based company should have a tendency to product innovation, innovative capabilities and the ability to create knowledge (B3), situational advantage (B6), and cost leadership (B2).

In comparison with other researches, it seems that the present study has more scrutiny, accuracy, depth and comprehensiveness and uses more influential and impressionable variables that can be used as an operational pattern for knowledge-based companies. This research has been conducted in the active knowledge-based companies in the field of electronics and informatics that can reveal an effective pattern for these companies. Considering the mentioned variables and indicators can lead such companies to reach the summit and gain a competitive advantage. For more convergence, it is suggested that the other researchers conduct similar studies in other knowledge-based fields.

\section{References}

Almus, M., \& Nerlinger, E. A. (1999). Growth of new technology-based firms: which factors matter? Small Business Economics, 13(2), 141-154. https://doi.org/10.1023/A:1008138709724

Ambe, I. M. (2010). Agile supply chain: strategy for competitive advantage. Journal of Global Strategic Management, 4(1). https://doi.org/10.20460/JGSM.2010415835

Ambrosini, V., \& Bowman, C. (2009). What are dynamic capabilities and are they a useful construct in strategic management? International Journal of Management Reviews, 11(1), 29-49. https://doi.org/10.1111/j.1468-2370.2008.00251.x

Badawy, A. M. (2008). Fast Strategy: How Strategic Agility Will Help You Stay Ahead of the Game. Journal of $\begin{array}{llll}\text { Engineering and Technology } & \text { 342-344. }\end{array}$ https://doi.org/10.1016/j.jengtecman.2009.10.007

Banker, R. D., Mashruwala, R., \& Tripathy, A. (2014). Does a differentiation strategy lead to more sustainable financial performance than a cost leadership strategy? Management Decision.

Barney, J. B. (1991). Firm Resources and Sustained Competitive Advantage. Journal of Management, 17(1), 99-120. https://doi.org/10.1177/014920639101700108

Barrales-Molina, V., Benitez-Amado, J., \& Perez-Arostegui, M. N. (2010). Managerial perceptions of the 
competitive environment and dynamic capabilities generation. Industrial Management \& Data Systems, 110(9), 1355-1384. https://doi.org/10.1108/02635571011087437

Barrena, R., \& Sánchez, M. (2009). Using emotional benefits as a differentiation strategy in saturated markets. Psychology \& Marketing, 26(11), 1002-1030. https://doi.org/10.1002/mar.20310

Berger, J., \& Heath, C. (2007). Where consumers diverge from others: Identity signaling and product domains. Journal of Consumer Research, 34(2), 121-134. https://doi.org/10.1086/519142

Berger, J. A., Heath, C., \& Ho, B. (2005). Divergence in cultural practices: Tastes as signals of identity. https://doi.org/10.1037/e633942013-916

Bhattacharya, C. B., \& Sen, S. (2003). Consumer-company identification: A framework for understanding consumers' relationships with companies. Journal of Marketing, 67(2), $76-88$. https://doi.org/10.1509/jmkg.67.2.76.18609

Bogodistov, Y., Presse, A., Krupskyi, O. P., \& Sardak, S. (2017). Gendering dynamic capabilities in micro firms. Revista de Administração de Empresas, 57(3), 273-282. https://doi.org/10.1590/s0034-759020170308

Byrd, T. A., \& Turner, D. E. (2001). An exploratory analysis of the value of the skills of IT personnel: Their relationship to IS infrastructure and competitive advantage. Decision Sciences, 32(1), 21-54. https://doi.org/10.1111/j.1540-5915.2001.tb00952.x

Cabral, J. E. D. O. (2010). Firms' Dynamic Capabilities, Innovative Types and Sustainability: A Theoretical Framework. Paper presented at the XVI International Conference on Industrial Engineering and Operations Management (ICIEOM).

Camisón, C. (2004). Shared, competitive, and comparative advantages: a competence-based view of industrial-district competitiveness. Environment and Planning A, 36(12), 2227-2256. https://doi.org/10.1068/a3759

Cooper, A. C. (1971). Spin-offs and technical entrepreneurship. IEEE Transactions on Engineering Management, 1, 2-6. https://doi.org/10.1109/TEM.1971.6447118

Das, S. R., \& Joshi, M. P. (2007). Process innovativeness in technology services organizations: Roles of differentiation strategy, operational autonomy and risk-taking propensity. Journal of Operations Management, 25(3), 643-660. https://doi.org/10.1016/j.jom.2006.05.011

Davenport, T. H., De Long, D. W., \& Beers, M. C. (1998). Successful knowledge management projects. Sloan Management Review, 39(2), 43-57.

Davenport, T. H., \& Prusak, L. (1998). Working Knowledge: How Organizations Manage What They Know. Harvard Business Press.

Distanont, A., \& Khongmalai, O. (2018). The role of innovation in creating a competitive advantage. Kasetsart Journal of Social Sciences, 41(1). https://doi.org/10.1016/j.kjss.2018.07.009

Easterby-Smith, M., Graça, M., Antonacopoulou, E., \& Ferdinand, J. (2008). Absorptive Capacity: A Process Perspective. Management Learning, 39(5), 483-501. https://doi.org/10.1177/1350507608096037

Eisenhardt, K. M., \& Martin, J. A. (2000). Dynamic capabilities: what are they? Strategic Management Journal, 21(10-11), 1105-1121. https://doi.org/10.1002/1097-0266(200010/11)

Eriksson, T. (2014). Processes, antecedents and outcomes of dynamic capabilities. Scandinavian Journal of Management, 30(1), 65-82. https://doi.org/10.1016/j.scaman.2013.05.001

Etzkowitz, H. (2006). The entrepreneurial university and the triple helix as a development paradigm. Paper presented at the Ethiopia Triple Helix Conference, Addis Ababa.

Evans, N. G. (2016). Sustainable competitive advantage in tourism organizations: A strategic model applying service dominant logic and tourism's defining characteristics. Tourism Management Perspectives, 18, 14-25. https://doi.org/10.1016/j.tmp.2015.12.015

Fowler, S. W., King, A. W., Marsh, S. J., \& Victor, B. (2000). Beyond products: new strategic imperatives for developing competencies in dynamic environments. Journal of Engineering and Technology Management, 17(3-4), 357-377. https://doi.org/10.1016/S0923-4748(00)00029-1

Garvin, D. A. (1983). Spin-offs and the new firm formation process. California Management Review, 25(2), 3-20. https://doi.org/10.2307/41165001 
Grant, R. M., \& Baden-Fuller, C. (2004). A knowledge accessing theory of strategic alliances. Journal of management studies, 41(1), 61-84. https://doi.org/10.1111/j.1467-6486.2004.00421.x

Helfat, C. E., Finkelstein, S., Mitchell, W., Peteraf, M., Singh, H., Teece, D., \& Winter, S. G. (2009). Dynamic capabilities: Understanding strategic change in organizations. John Wiley \& Sons.

Hill, C. W. L., \& Jones, G. R. (2007). Strategic Management: An Integrated Approach (8th ed.). Cengage Learning.

Jantunen, A., Ellonen, H.-K., \& Johansson, A. (2012). Beyond appearances-do dynamic capabilities of innovative firms actually differ? European Management Journal, 30(2), 141-155. https://doi.org/10.1016/j.emj.2011.10.005

Jennex, M. E., \& Durcikova, A. (2013). Assessing knowledge loss risk. Paper presented at the 2013 46th Hawaii International Conference on System Sciences. https://doi.org/10.1109/HICSS.2013.103

Kak, A., \& Sushil, H. (2002). Sustainable competitive advantage with core competence: a review. Global Journal of Flexible Systems Management, 3(4), 23-38.

Klepper, S., \& Sleeper, S. (2005). Entry by spinoffs. Management Science, 51(8), 1291-1306. https://doi.org/10.1287/mnsc.1050.0411

Kosonen, M., \& Dotz, Y. (2007). Fast Strategy: how Strategic Agility will help you stay ahead of the game. Pearson Education UK.

Kumar, P., Dass, M., \& Kumar, S. (2015). From competitive advantage to nodal advantage: Ecosystem structure and the new five forces that affect prosperity. Business Horizons, 58(4), 469-481. https://doi.org/10.1016/j.bushor.2015.04.001

Lawler III, E. E. (1994). From job-based to competency-based organizations. Journal of organizational behavior, 15(1), 3-15. doi: https://doi.org/10.1002/job.4030150103

Li, S., Ragu-Nathan, B., Ragu-Nathan, T., \& Rao, S. S. (2006). The impact of supply chain management practices on competitive advantage and organizational performance. Omega, 34(2), 107-124. https://doi.org/10.1016/j.omega.2004.08.002

Lorenzo, J. R. F., Rubio, M. T. M., \& Garcés, S. A. (2018). The competitive advantage in business, capabilities and strategy. What general performance factors are found in the Spanish wine industry? Wine Economics and Policy, 7(2), 94-108. https://doi.org/10.1016/j.wep.2018.04.001

Lumpkin, G. T., \& Dess, G. G. (1996). Clarifying the entrepreneurial orientation construct and linking it to performance. Academy of Management Review, 21(1), 135-172. https://doi.org/10.5465/amr.1996.9602161568

Mahdi, O. R., \& Almsafir, M. K. (2014). The role of strategic leadership in building sustainable competitive advantage in the academic environment. Procedia-Social and Behavioral Sciences, 129, 289-296. https://doi.org/10.1016/j.sbspro.2014.03.679

Massingham, P. (2008). Measuring the impact of knowledge loss: more than ripples on a pond? Management Learning, 39(5), 541-560. https://doi.org/10.1177/1350507608096040

Masteika, I., \& Čepinskis, J. (2015). Dynamic capabilities in supply chain management. Procedia-Social and Behavioral Sciences, 213, 830-835. https://doi.org/10.1016/j.sbspro.2015.11.485

Muthusamy, S. K., \& Palanisamy, R. (2004). Leveraging cognition for competitive advantage: a knowledge-based strategy process. Journal of Information \& Knowledge Management, 3(3), 259-272. https://doi.org/10.1142/S0219649204000870

Newton, S. K., Gilinsky Jr, A., \& Jordan, D. (2015). Differentiation strategies and winery financial performance: An empirical investigation. Wine Economics and Policy, 4(2), 88-97. https://doi.org/10.1016/j.wep.2015.10.001

Nicolescu, O. (2006). Knowledge Based Strategy. Zagreb International Review of Economics \& Business, Special Conference Issue (SCI)(1), 111-125.

Nonaka, I., \& Takeuchi, H. (1995). The knowledge-creating company: How Japanese companies create the dynamics of innovation. Oxford university press. https://doi.org/10.1016/0024-6301(96)81509-3

Nonaka, I., Von Krogh, G., \& Voelpel, S. (2006). Organizational knowledge creation theory: Evolutionary paths and future advances. Organization Studies, 27(8), 1179-1208. https://doi.org/10.1177/0170840606066312 
Paun, D. (1993). When to bundle or unbundle products. Industrial Marketing Management, 22(1), 29-34. https://doi.org/10.1016/0019-8501(93)90017-2

Pavlou, P. A., \& El Sawy, O. A. (2011). Understanding the elusive black box of dynamic capabilities. Decision Sciences, 42(1), 239-273. https://doi.org/10.1111/j.1540-5915.2010.00287.x

Porter, M. E. (1990). New Global Strategies for Competitive Advantage [General review]. Strategy \& Leadership, 18(3), 4-14. https://doi.org/10.1108/eb054287

Pundziene, A., \& Teece, D. J. (2016). New applications of dynamic capability research. Baltic Journal of Management, 11(3). https://doi.org/10.1108/BJM-05-2016-0103

Rannikko, H. (2012). Early Development of New Technology-Based Firms: A Longitudinal Aanalysis on New Technology-Based Firms' Development from Population Level and Firm Level Perspectives.

Rivard, S., \& Huff, S. L. (1988). Factors of success for end-user computing. Communications of the ACM, 31(5), 552-561. https://doi.org/10.1145/42411.42418

Rong, H., Hongshan, X., \& Jiang, Y. (2013). Complex dynamics for airlines' price competition with differentiation strategy. Journal of Transportation Systems Engineering and Information Technology, 13(1), 11-16. https://doi.org/10.1016/S1570-6672(13)60091-4

Rosenbaum-Elliott, R., Percy, L., \& Pervan, S. (2015). Strategic Brand Management (illustrated ed.). USA: Oxford University Press.

Roundy, P. T., \& Fayard, D. (2018). Dynamic capabilities and entrepreneurial ecosystems: the micro-foundations of regional entrepreneurship. The Journal of Entrepreneurship, 28(1), 94-120. https://doi.org/10.1177/0971355718810296

Rumelt, R. P. (2003). What in the world is competitive advantage. Policy Working Paper, 105(2003), 1-5.

Rzepka, A. (2017). Inter-organizational relations as a one of sources of competitive advantage of contemporary enterprises in the era of globalization. Procedia Engineering, 174, 161-170. https://doi.org/10.1016/j.proeng.2017.01.195

Saeidi, P., Saeidi, S. P., Sofian, S., Saeidi, S. P., Nilashi, M., \& Mardani, A. (2019). The impact of enterprise risk management on competitive advantage by moderating role of information technology. Computer Standards \& Interfaces, 63, 67-82. https://doi.org/10.1016/j.csi.2018.11.009

Salvato, C., \& Vassolo, R. (2018). The sources of dynamism in dynamic capabilities. Strategic Management Journal, 39(6), 1728-1752. https://doi.org/10.1002/smj.2703

Sheehan, N. T., \& Stabell, C. B. (2010). Reputation as a driver in activity level analysis: reputation and competitive advantage in knowledge intensive firms. Corporate Reputation Review, 13(3), 198-208. https://doi.org/10.1057/crr.2010.19

Souza, I. M. d. (2012). Gestão das Universidades Federais Brasileiras: uma abordagem fundamentada na gestão do conhecimento.

Stewart, B. (1996). Packaging as an Effective Marketing Tool (Pira Packaging Guide) (1st ed.). CRC Press.

Teece, D. J. (2007). Explicating dynamic capabilities: the nature and microfoundations of (sustainable) enterprise performance. Strategic Management Journal, 28(13), 1319-1350. https://doi.org/10.1002/smj.640

Teece, D. J. (2018a). Business models and dynamic capabilities. Long Range Planning, 51(1), 40-49. https://doi.org/10.1016/j.lrp.2017.06.007

Teece, D. J. (2018b). Dynamic capabilities as (workable) management systems theory. Journal of Management \& Organization, 24(3), 359-368. https://doi.org/10.1017/jmo.2017.75

Tuten, T. (2010). Enterprise 2.0: How Technology, eCommerce, and Web 2.0 Are Transforming Business Virtually. Praeger.

Venkatesh, S., Berry, L. L., \& Dotzel, T. (2009). A Practical Guide to Combining Products and Services. Harvard Business Review, 87(11), 16-19.

Volberda, H. W., Foss, N. J., \& Lyles, M. A. (2010). Perspective-Absorbing the concept of absorptive capacity: How to realize its potential in the organization field. Organization Science, 21(4), 931-951. https://doi.org/10.1287/orsc. 1090.0503 
Wang, C. L., \& Ahmed, P. K. (2007). Dynamic capabilities: A review and research agenda. International Journal of Management Reviews, 9(1), 31-51. https://doi.org/10.1111/j.1468-2370.2007.00201.x

Whitehill, M. (1997). Knowledge-based strategy to deliver sustained competitive advantage. Long Range Planning, 30(4). https://doi.org/10.1016/S0024-6301(97)00046-0

Wiklund, J., \& Shepherd, D. (2003). Knowledge-based resources, entrepreneurial orientation, and the performance of small and medium-sized businesses. Strategic Management Journal, 24(13), 1307-1314. https://doi.org/10.1002/smj.360

Winter, S. G. (2003). Understanding dynamic capabilities. Strategic Management Journal, 24(10), 991-995. https://doi.org/10.1002/smj.318

Ya-Hui, H., \& Chia-Hsiu, C. (2015). Clustering of Tea Processing Industry Based on GIS Analysis. International Journal of Agricultural Sciences and Natural Resources, 2(3), 58-66.

Zack, M. H. (1999). Developing a knowledge strategy. California Management Review, 41(3), 125-145. https://doi.org/10.2307/41166000

\section{Copyrights}

Copyright for this article is retained by the author, with first publication rights granted to the journal.

This is an open-access article distributed under the terms and conditions of the Creative Commons Attribution license (http://creativecommons.org/licenses/by/4.0/). 